\title{
J.V. FOIX: UNA ALTRA LECTURA EN LLIBRES D’ARTISTA
}

\author{
EVA FIGUERAS FERRER
}

\begin{abstract}
If we add talent, restlessness and creativity to the journalistic and literary vocation of J.V. Foix, and his eagerness to investigate everything "new" without neglecting tradition, he is clearly a universal character with a very significant legacy in our Catalan culture. This article considers the reading of Foix from a perspective in which the printed word and the creative image converge in the artist's book. In collaboration with prominent artists such as Joan Miró, Joan Ponç and Antoni Tàpies, Foix leaves us a legacy in varied and original artist's books. The work is sometimes the result of a combined effort, and on other occasions it is the visual and poetic testimony of another way of feeling and expressing oneself. In both cases, we will witness how the literary creation of one aspect strengthens and enriches the artistic creation of the other.
\end{abstract}

\section{INTRODUCCIÓ}

A principis de segle $\mathrm{XX}$, les circumstàncies geogràfiques i sociohistòriques de Catalunya porten el nostre país a buscar una personalitat literària i artística pròpia en contacte amb els corrents avantguardistes europeus, especialment els moviments literaris francesos.

Les influències avantguardistes aviat es deixen veure a Catalunya gràcies a les manifestacions artístiques a la Galeria Josep Dalmau i a les publicacions de revistes de tendència avantguardista com són: Trossos (1916) —que manté relació amb dues revistes franceses d'avantguarda (Sic i Nord-Sud) i noms com Apollinaire, Tzara i Max Jacob s'esmenten sovint a les seves pàgines_-, 391 (1917) — publicada per Picabia i impresa a la Galera Dalmau, hi podem trobar fotografies de Man Ray i escrits de Aragon, Breton, Desnos, Eluard, Magritte i Soupault-, Arc voltaic (1918) de Joan Salvat Papasseit, L'Instant (1919) —on s'hi publiquen textos de Tzara, Reverdy i Josep Maria Junoy_, Monitor (1921) — apareguda a Sitges i dirigida per Carbonell i Foix - i, també a Sitges i amb influències pròpiament surrealistes, apareix L'Amic de les arts (1926-1929), entorn de la qual s'aglutinà el grup més actiu de crítics, artistes i poetes de l'avantguarda catalana. Junt al seu director, Josep Carbonell, figura l'equip de redacció amb J.V. Foix, M.A. Cassanyes, Ramon Planes, Salvador Dalí, Lluís Montanyà, Sebastià Gasch, Sánchez-Juan, i la col-laboració de Joan Miró — “which provided constant illustrations of the new mode of painting stimulated by surrealist theory and practice" (Morris 15). 
Pendent de les darreres tendències literàries i artístiques, apareixen publicades a la revista obres visuals de Man Ray, Chagall, Dalí, Ernst, Lorca, Léger, Miró i escrits de Aragon, Breton, Desnos, Eluard, Baron, Lautréamont, Magritte i Soupault, entre d'altres. ${ }^{1}$

J.V. Foix (Sarrià, 1893-Barcelona, 1987), com a creador i com activista de L'Amic de les arts, va viure i prendre part d'aquests moviments estètics europeus. Dos moviments d'avantguarda influeixen de manera notable a l'escriptor català: el futurisme, que representa l'obertura a la innovació, i el surrealisme, que és l'encontre d'una nova tècnica de composició literària de la qual la producció foixiana ja no es podrà desprendre: "Foix put trust in the atzar and in the insegur pursued by the surrealist to transform his own poetic role" (Morris 78). Malgrat el seu posicionament dins de la revista L'Amic de les arts i malgrat reconèixer l'impacte i la producció surrealista, Foix, com Montanyà, van mostrar-s'hi, a vegades "poc entusiastes" (Morris 16). Foix insisteix en el fet que la seva aventura avantguardista posseeix uns sòlids fonaments clàssics ${ }^{2}$, tot i que sembli paradoxal, i així ho manifesta diverses vegades en els seus articles a revistes ${ }^{3}$ i en la seva producció literària, que es podria resumir en el vers “m'exalta el nou i m'enamora el vell".

Aquesta curiosa síntesi d'elements lírics tradicionals i avantguardisme confereix una personalitat especial a l'estil de l'autor i "alhora mostra que la combinació de modernitat i tradició, a primer cop d'ull contradictòria, és, tanmateix, possible” (Tricàs 69). Aquesta peculiaritat també la compartirà amb el seu amic Miró i queda reflectida en el llibre Quatre colors aparien el món..., que valorarem seguidament. També, com Miró, J.V. Foix va propugnar un catalanisme ètic i cívic ${ }^{4}$ i es va destacar per la seva defensa de la investigació i de l'experimentació en la literatura i en l'art.

La vida i la producció foixiana està lligada als artistes catalans més actius i representatius de l'època: Amb els seus coetanis Joan Miró i Salvador Dalí —que juntament amb Max Ernst, seran els exponents del surrealisme europeu- els va unir una relació d'amistat i de col-laboració que va perdurar al llarg de la seva vida. Per la generació de pintors més joves, com són en Tàpies o Ponç, J.V. Foix va representar la porta cap a Europa, és a dir, la font d'informació i de coneixements de l'art d'avantguarda que es practicava més enllà de les nostres fronteres. El poeta, per l'altra banda, veia en els joves pintors l'esperit trencador, investigador i inconformista indispensable per la creació i la generació de noves idees. Amb tots ells va mantenir una relació i una col·laboració més o menys assídua que es nodria mútuament i que, avui en dia, la veiem reflectida, en part, en els magnífics llibres d'artista que tot seguit valorarem. 


\section{J.V. FOIX I JOAN MIRÓ, NATS SOTA UNA MATEIXA ESTRELLA}

Entre J.V. Foix i Joan Miró (Barcelona 1893-Palma de Mallorca 1983) es va establir una amistat marcada pel respecte mutu i l'admiració des del moment en que es van conèixer pels volts de l'any 1917, quan Enric Cristòfor Ricart, amic íntim de Miró, els va presentar a l'estació del tren de Vilanova. Cristòfor Ricart va predir que Foix i Miró havien nats sota la mateixa estrella. I certament els dos compartien les mateixes inquietuds, projectes d'avantguarda de la preguerra, com ara la revista L'Amic de les arts de Sitges, el grup ADLAN ${ }^{5}$ i la recuperació de l'esperit d'avantguarda després de la guerra.

J.V. Foix anomena Miró "pessebrista astral" i, en un article aparegut a $\mathrm{La}$ Publicitat (29-IV-1932), ${ }^{6}$ distingeix la producció del pintor català de la dels surrealistes franceses, ja que "els seus 'objectes', tot i certes arbitràries insinuacions, no entren dins la classificació que de la nova plàstica han fet els amics de Breton" i argumenta que "la diferència entre els objectes de Miró i els surrealistes no és solament quant a l'apreciació de l'origen i la manifestació de l'automatisme, sinó en la puresa d'intencions" (Carbonell 511-512). Rosa Maria Malet també diferencia l'obra de Miró de la dels surrealistes argumentant que aquests darrers abandonen el model exterior i només consideren vàlid allò que prové del subconscient: "Miró no pinta sueños sino que, a través de su obra, pone a disposición del espectador ciertos elementos para que sea éste quien sueñe" (Malet 11). Segons Malet, Miró no va treballar mai sota els efectes de la hipnosi, de les drogues o l'alcohol, i la seva vida "igual que su pintura, ha sido siempre metódica y ordenada". Aquest caràcter metòdic i ordenat en l'obra mironiana és el mateix que li atribueix Mercè Tricàs a Foix en el seu estudi J.V. Foix i el surrealisme: "J.V. Foix sembla mostrar sempre un control més gran en la creació d'aquestes associacions [surrealistes] i poques vegades trobem en la seva escriptura la cascada desordenada i incontrolable de paraules que conformen alguns textos del surrealisme francès" (Tricàs 200).

No obstant aquesta diferencia substancial del pintor català respecte dels surrealistes francesos, llur personalitat artística i la manera de representar sobre la tela el què li ve donat per la inspiració farà exclamar a André Breton: "Miró es más surrealista que todos nosotros" (Malet 11). Efectivament, Miró va ser admirat pels surrealistes francesos i va colllaborar amb André Breton - especialment interessant és Constellations ${ }^{7}$ - Tristan Tzara, Paul Eluard i Robert Desnos, entre d'altres. $^{8}$

Quant a l'origen del seu art, i com un altre tret diferencial dels surrealistes europeus i com a punt comú amb Foix, Miró produeix una pintura que recull "totes les peculiaritats plàstiques, essencials, de la pintura medieval catalana, tot allò que hi ha de més autòcton" i "no solament resum totes les temptatives de creació independent remarcades en el procés de la història de la pintura catalana, ans en 
supera la intenció per oferir dins el quadre de la pintura europea hodierna una expressió independent i una personalitat inconfusible" (Carbonell 514). Sens dubte, una de les coses que més valorava el poeta en l'artista plàstic era el seu caràcter d'intèrpret exemplar de trets essencials de la catalanitat. Pintor universal, el que avala l'originalitat i la potència de l'obra, en el seu conjunt, és la fidelitat a "tot allò que hi ha de més autòcton" (Foix "Dada" 48). I comparant-lo amb les realitzacions pictòriques dels artistes europeus entre els quals hi hagi possibilitat d'establir un denominador comú d'escola, l'escriptor afirma "que només Joan Miró manté una realitat ràcica i temperamentalment indiscutible [...] nodrida a través dels segles per unes característiques locals (en l'ordre geogràfic): simplicitat, claredat, objectivitat i, no rebutgem la paradoxa, REALISME" (Carbonell 514-515).

En el llibre d'artista Quatre colors aparien el món..., 9 realitzat pel tàndem Foix-Miró, s'evidencia ràpidament la complicitat i la compenetració entre els dos autors. Publicat l'any 1975 per Gustavo Gili, és un treball sensible que aconsegueix complicitats irrepetibles i constitueix un bellíssim exemplar de la comunió entre literatura i art a mans de dos autors excepcionals de la nostra cultura. Creat en una etapa de maduresa dels autors, a Quatre colors aparien el món... podem trobar-hi alguns dels postulats que compartien i defensaven en sendes produccions. La dialèctica constant entre la realitat-real i la forma superior de 'realitat' — que els surrealistes persegueixen- produeix contínues mutacions i transformacions en els objectes visibles. Com veurem, el color juga un paper molt destacat en la transformació de la realitat i acosta l'escriptura foixiana a l'univers pictòric de Miró, convertint l'obra objecte d'estudi en una comunió perfecte entre ambdues disciplines.

Segons Carbonell a Quatre colors aparien el món... el contingut moral i/o meditatiu s'hi encarnava en imatges:

Segueix la tècnica narrativa de contar un episodi que comença amb una situació banal que de sobte es transforma, per la irrupció d'un element insignificant en ell mateix però que en aquell context pren una dimensió absolutament extraordinària i, com a tal, metamorfosadora, i dóna lloc al desamagament de l'altra cara del real, el 'real poètic'. Aquí això s'acompleix de la mà de la pintura de Miró, la qual serveix a Foix per a 'transcriure' el salt cap a l'elemental propi d'aquesta obra en un gest indicatiu per comprendre la seva pròpia concepció poètica (Carbonell 116).

J.V. Foix va redactar el text en homenatge als colors de Miró. Prenent per base quatre colors (i, curiosament, deixant de banda el blau, color mironià per excel-lència) l'escriptor va articular quatre històries en les quals la realitat apareixia transfigurada pel meravellós o l'inversemblant. El negre era el del quitrà, el vermell era el del foc, el groc era el de l'infinit i el blanc el de la llum. En Joan Miró, tal com J.V. Foix l'anomenava, hi era descrit com un personatge "entestat" i "rioler", 
que feia veure que no veu ningú i que espiava i veia a tothom, i que adoptava de J.V. Foix la idea segons la qual "amb els ulls tancats el real se us feia divinament concret".

Els aiguaforts i les aiguatintes que acompanyen el text són un clar exponent dels personatges de Miró, i entaulen una conversa, frec a frec, amb el text escrit, amb el que es diu i el que no es diu, amb el real i l'imaginari.

Del relat Groc, es traspua el to entre crític i irònic de Foix quan es refereix als imitadors del pintor: “... tots ells emmironiats, vull dir que, alts o baixos, prims o panxuts, peluts o mecs, els esquiadors, imitadors o deixebles i de murrieria segons escau als adeptes de la plàstica futuritzant-, reproduïen els trets físics del nostre cap de brot. Dotzenes de Mirós, doncs...” (Foix, Obres 465). I divertida és l'autocrítica que s'imputa Foix en boca del seu amic:

Escolteu, Foix, i creieu-me. Aneu massa encollat i encasquetat i sou poc retribuït. Mireu massa de lluny i espieu poc als altres. Jo, ja ho veieu; simulo que no veig res ni ningú, però, de reüll, els guaito i espio tots. Sé el que fan, el que innoven, el que copien i el que esguerren, massa sovint desencertats, i n'aprofito allò que em pot servir. I em tinc tan dret com vós, gairebé sense mullar-me els peus ni enaiguar els esquís (Foix, Obres 465).

La presència de l'autor en el text, característica típicament surrealista, provoca una estranya combinació de passatges autobiogràfics, de segments provinents del subconscient de l'escriptor i d'altres segments diversos. En definitiva es produeix una íntima connexió entre l'escriptor i la seva obra, de manera que moltes de les estranyes accions que l'escriptura presenta tenen relació directa amb la vida conscient i inconscient de l'autor. André Breton, en el Segon Manifest, insistí en les vivències procedents de l'interior de l'escriptor “L'idée du Surréalisme tend simplement a la récupération de notre force psychique par un moyen qui n'est pas autre que la descente vertigineuse en nous, l'illumination systématique des lieux cachés, et l'obscurcissement progressif des autres lieux, la promenade perpétuelle en pleine zone interdite" (Breton, Le surréalisme 92).

Quant el relat Blanc, tot fent referència a la 'llum', o a la 'clarividència' o a la 'no por' vers el desconegut, hi llegim: “Com més orb em reconeixia, més llum captava [...] les blancors, amb devessall de silencis, ultrapassaven els límits de la meva comprensió. Verament m'havia tornat cec, [...] quan una mà ferma, càlida, confident i segura aferrava la meva, i una veu candorosa em deia: No tingueu por, jo us acompanyo" (Foix, Obres 466). I anant plegats pels camins del desconegut en Foix comenta a Miró que és cec però "ho endevino tot immensament clarós. - No temeu - va respondre En Miró—. Conec, de sobres, els camins. També ho sóc jo, de cec, com vós. I ja veieu com tresco. ¿No vau ésser vós mateix, Foix, que em vau dir un dia que només amb els ulls tancats el real se feia divinament concret?" (Foix, Obres 467). En certa manera aquesta noció surrealista del món dels somnis on tot 
és possible és reincident en el pensament foixià i recorda el títol d'un dels poemes més coneguts de l'escriptor, "És quan dormo que hi veig clar", de l'any 1939.10

Aquests nexes de pensament compartit s'enforteixen quan es descriuen els colors en la paleta mironiana, especialment pel que fa referència al negre, color central en la obra de Miró i símbol del poder creador humà $i$, en conseqüència, del seu. Vallès, en un article molt interessant dedicat a l'univers simbòlic de Miró, comenta que "el negre [en Miró] es el color de la nit, el moment de la germinació lenta, soterrada, quasi imperceptible de la vida" (Vallès 158). Efectivament, resulta fàcil endevinar perquè Miró, com a poeta de la vida i de les seves potencialitats, va fer del negre - color associat generalment al buit, al silenci, a les tenebres- la metàfora privilegiada de la seva obra creadora.

Curiosament, per a Miró, el color negre no era un color mort. Al contrari, era l'embrió silenciós i cridaner de tots els altres colors, com va revelar al seu amic J.V. Foix, segons el diàleg imaginari d'aquest últim amb Miró: "Escolteu, Foix [...] El negre que jo propugno i provo d'evocar es orgànic, articulat y vigorós, no sé si em faré comprendre, com de vori cremat, un negre amb blancs latents" (Foix, Obres 460).

En la majoria d'estampes de Quatre colors aparien el món... (Fig. 1) Miró posa ulls al personatge que representa. El traç vermell en un d'ells ens revela que el "mirar" dels seus ulls de l'ànima tindria aquest poder de radiació infraroja, capaç d'il-luminar i desvetllar la vida oculta o essencial de totes les coses: "Allà on pensem d'anar, allà som tantost, i les dreceres s'escurcen amb l'afany" (Foix, Obres 462).

L'ull, detall figuratiu elemental, així com també els 'tres pels', tot just volen ressaltar, de manera incisiva la seva identitat humana com a pintor, que el mateix nom Miró/miroir/mirer... li urgiria. Alhora, la presència dels asteroides formats per les taques dels colors primaris i secundaris i la del negre, reafirmen aquesta mateixa identitat de poeta dels colors i de la seva plena autonomia, així com exerceixen, en aquest context, de contrapunt per a ressaltar la correlada grandesa humana-divina de la seva gesta existencial creadora.

L'espectador es troba sacsejat enèrgicament per intuïcions poètiques penetrants que, en ocasions, són l'equivalent de metàfores fantàstiques. El mateix Miró va dir, més o menys, en una ocasió: "La meva pintura conté procediments poètics, fins i tot rimes. Per exemple, els braços d'una dona poden correspondre a les banyes de la lluna”. Sens dubte, la colllaboració entre Miró i J.V. Foix ha llegat unes de les obres més profundes i misterioses del nostre temps i és fàcil comprendre que ambdós artistes compartissin una visió similar del món. A través de llur llenguatge, visual i escrit, la percepció de l'espectador multiplica la seva potència, tal com ens passa amb les imatges somiades i amb els desitjos només imaginats. Què té d'estrany doncs, que, referint-se a aquest tàndem Foix-Miró, alguns crítics hagin 

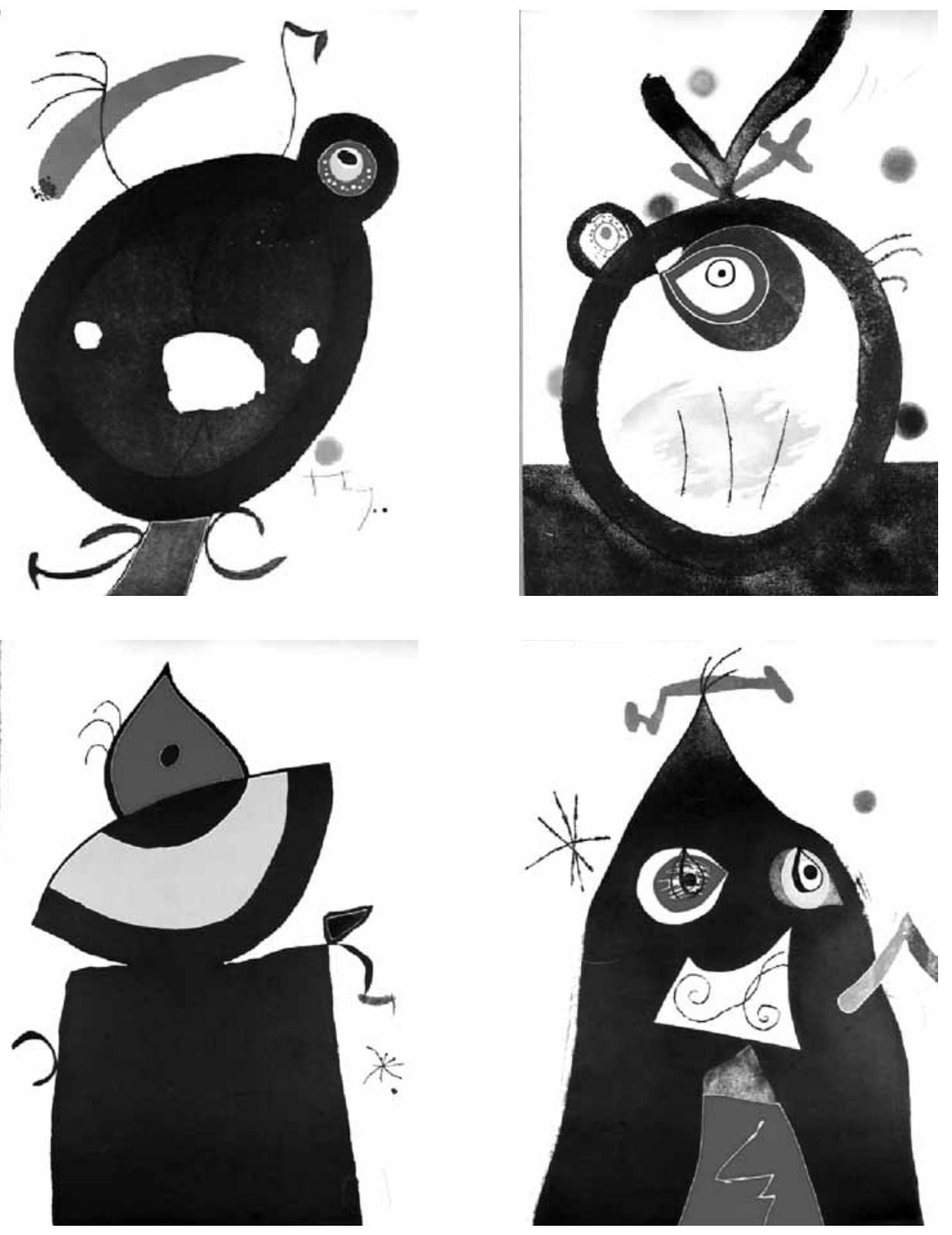

Fig. 1 Quatre estampes de Joan Miró. Quatre colors aparien el món...

citat freqüentment la paraula màgia? (Vicens 17). Parlant de màgia, l'artista mag que va col·laborar amb J.V. Foix és en Joan Ponç. 


\section{J.V. FOIX I JOAN PONÇ, AVANTGUARDISTES QUE NO DEIXEN DE TOCAR DE PEUS EN LA TRADICIÓ}

En l'ambient decaigut de la Barcelona de postguerra, l'afany per obrir nous horitzons en l'art i la poesia va apropar a tota una generació d'artistes i poetes als recursos del corrent surrealista a través de J.V. Foix i Joan Miró. Es van aglutinar entorn de la revista Dau al set (1948), considerada la primera i més important manifestació de l'avantguardisme espanyol de postguerra. Els membres fundadors van ser el poeta Joan Brossa (que va crear el nom del grup i de la revista), el filòsof Arnau Puig i els pintors Joan Ponç (director de la revista), Antoni Tàpies, Modest Cuixart i Joan-Josep Tharrats (editor i impressor de la revista). Al cap de poc de crear-se el grup se'ls va unir Juan-Eduardo Cirlot.

Joan Ponç (Barcelona, 1927-Sant Pau de Vença, 1984) va ser un dels principals instigadors de la revista i va colllaborar estretament amb poetes i escriptors de la seva època, com són J.V. Foix, Joan Fuster, Joan Brossa, Luis Goytisolo, José Corredor-Matheos, entre d'altres. Amb en Foix va publicar La pell de la pell $(1970)^{11}$ i 97 notes sobre ficcions poncianes (1974). ${ }^{12}$ Ambdós llibres d'artista són una mostra de l'estret lligam teixit entre dos creadors de generacions distants que, tot i treballar amb materials diferents, compartien una mateixa manera d'entendre la creació. Els unia la mateixa convicció que l'art no es pot entendre sense un profund coneixement de la tradició però, al mateix temps, sense un gran compromís amb la descoberta, l'agosarament i la modernitat. Certament, poeta i pintor eren avantguardistes, però eren avantguardistes que no deixaven de tocar de peus en la tradició. Foix ho resumeix en el seu famós vers "M'exalta el nou i m'enamora el vell" i de Ponç comenta que "el nostre pintor calça el peu dret amb coturn i l'esquerre amb espardenya" (Foix, Obres 321).

Els resultats més interessant de la colllaboració Foix-Ponç corresponen als que podríem considerar la segona etapa plàstica del pintor, després de tornar del Brasil, l'any 1962. Al Brasil, en Ponç contacta amb la màgia negre i, tal com ell declara, s'hi sent identificat: "és l'únic país on l'amor meu a la màgia, essència del meu art, podrà trobar un ambient propi".

Home solitari, minuciós i detallista fins a l'extrem, pretenia ésser un visionari del misteri i dels secrets de l'esperit. El seu món és dels més personals de la seva època. Ple de personatges i signes cabalístics, ofereix escenes oníriques, patètiques, torturades, en què el món del subconscient és presentat com a protagonista. I és aquest neosurrealisme màgic, proper a les fantasmagories i a la imaginació incondicionada, que Foix exalta a La pell de la pell, el 1970:

Va ésser aleshores que algú va modificar la dita i va parlar de la pell de la pell. Vós, Ponç, que hi éreu, vau parlar de la pell que batega sota la pell, no pas com un romàntic mal 
deslletat, o un decadent amorós del tèrbol: ni tampoc com un naturalista cru i nu, sinó com el poeta que s'esforça per esquivar el rònec on vagareja, fer llum al magatzem dels accessoris i provocar el Fet, il-luminant per secretes clarors diürnes, i sense malefici.

Vós, Joan Ponç us heu adonat com la troballa del meravellós espellussat allibera la ment, aviva els sentits i prova la nostra innocència (Foix, Obres 305).

I també a 97 notes sobre ficcions poncianes, quan Foix es refereix a Ponç com "alògic i desenraonat —en aparença?-, diria hom que salta el seny per atènyer el bagueny on els astres s'esgrunen...". I més endavant comenta que "sovint el pintor va més enllà d'ell mateix, i ha de córrer, rabent, per atrapar-se i reintegrar-se" (Foix, Obres 307-308).

Innegablement, Foix sent una gran admiració pel pintor i es pregunta “ ¿Com copsa En Joan Ponç, de quina antena extrema es val per a captar aquest univers que conté un món del qual no sabem si és ençà o enllà del que petgem?". Foix també defensa la pintura ponciana que "alguns diuen 'Màgia'; d'altres 'Ocultisme!'; els de més enllà: 'Neurosi!'. Hi ha qui ens proposa de pensar en els místics o en els platonitzants. No és pas ben bé això i així" perquè "les pintures poncianes... les coses aparencen el que no són. Però la descoberta i la invenció hi són simultànies. Existeixen alhora...” (Foix, Obres 321). Prudon referma la dissertació foixiana: "Toujours, chez Ponç, la peinture considérée comme exutoire, la purgation, la catharsis et, dans le même temps, peinture-laboratoire où l'expérience de la perception est conduite jusqu'à la limite, non pas observation/description de l'image mais étude/examen de la manière dont l'image se forme. C'est la recherche en écriture prônée par Foix” (139).

La iconografia fantàstica i demoníaca del pintor ve reforçada perquè la seva obra no es precipita cap a un abstracte absolut, conserva la representació de les formes, de la realitat, encara que impregnades de somni. I és aquesta dialèctica entre la realitat-real i la imaginada o somniada per l'autor la que produeix en síntesi un món misteriós i insòlit. La diferència entre el codi surrealista i altres corrents que també tenen per referència el món de la fantasia, és que "el moviment d'André Breton intenta d'aconseguir [...] una mena de realitat 'total' que no sigui la negació de la realitat objectiva que ens envolta sinó la seva sublimació" (Tricàs 26), on la sobreposició d'elements procedents del món subjectiu de l'artista combinats amb elements procedents del món sensible produeixen la nova realitat surrealista. En el text La pell de la pell de Foix passa exactament el mateix. En la síntesi del món real i del món del misteri no se sap per on l'escriptor talla la realitat i el somni ${ }^{13}$. La història arrenca des d'un paisatge conegut (el Port de la Selva) i uns personatges que poden ser verídics i, a partir d'un moment de la narració, el protagonista (el Foix narrador) deixa de tocar de peus a terra i s'endinsa en el món dels somnis.

El territori on la realitat i el somni conflueixen es el més fèrtil per la creació 


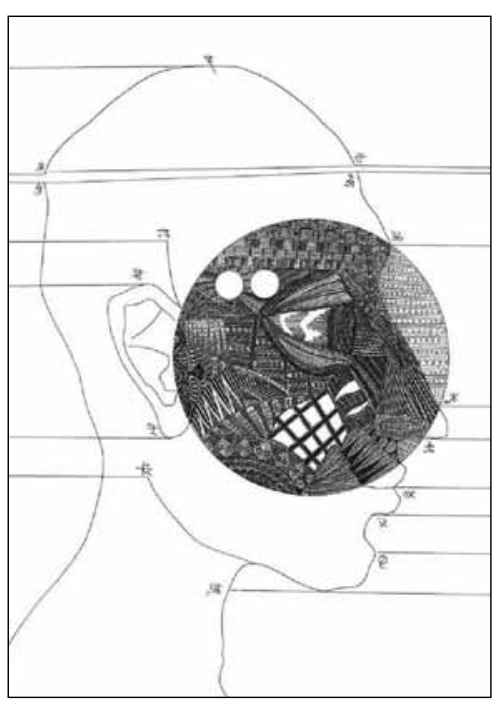

Fig. 2 La pell de la pell. Joan Ponç.

literària surrealista i com que aquest és, precisament, el territori on es mou Ponç ja no en la literatura sinó en el món de la plàstica一, això explica aquesta trobada tan brillant i colpidora com és La pell de la pell. ${ }^{14}$ En els vint-i-dos aiguaforts de la carpeta Ponç ens mostra amb nitidesa l'eix central de les seves inquietuds, el cos humà. Com a Gertrudis (1927) i KRTU (1932) de Foix, el cos apareix fragmentat, desfigurat, mutilat, contusionat i posat al límit per descobrir aquesta realitat que hi ha més enllà de l'aparença de la figura humana. ${ }^{15}$ Ponç no representarà una figura amb voluntat realista sinó que la portarà al límit de l'horror terrible i el riure grotesc: "Testes, ulls, orelles, pits, peus i cors, i, també, cabelleres amb afegitons trenats..." delaten la presència latent d'un cos que l'artista ens oculta. Són membres que ens remeten a "una sagristia de santuari amb exvots i presentalles a les parets" (Foix, Obres 309), objectes que són una ofrena i una súplica, fragments que alhora fan palès dolor i esperança. Tanmateix, aquesta fragmentació corporal i mental (Sobrer 186) és, segons Roser, "the first stage of alchemy, which is followed by a second stage where the reassembling of the broken parts creates something new, as can be seen in Foix and Ponç's work" (Roser 40-41).

Ponç (Fig. 2 ) ens obliga a fixar la nostra atenció en un punt concret del cos humà, ens dibuixa un recorregut per la geografia humana amb aturades en els punts que ell considerava claus: les mans, els ulls i el cap. Mans que intenten atènyer l'inabastable, com el pintor que amb els seus pinzells, llapis i burins s'esmerça a revelar allò que s'amaga darrere l'aparença de les coses. Ulls que amb la seva mirada intenten depassar la pell de l'aparença i furgar en l'essència. Caps que s'obren per copsar allò que no es pot atrapar amb els sentits. 


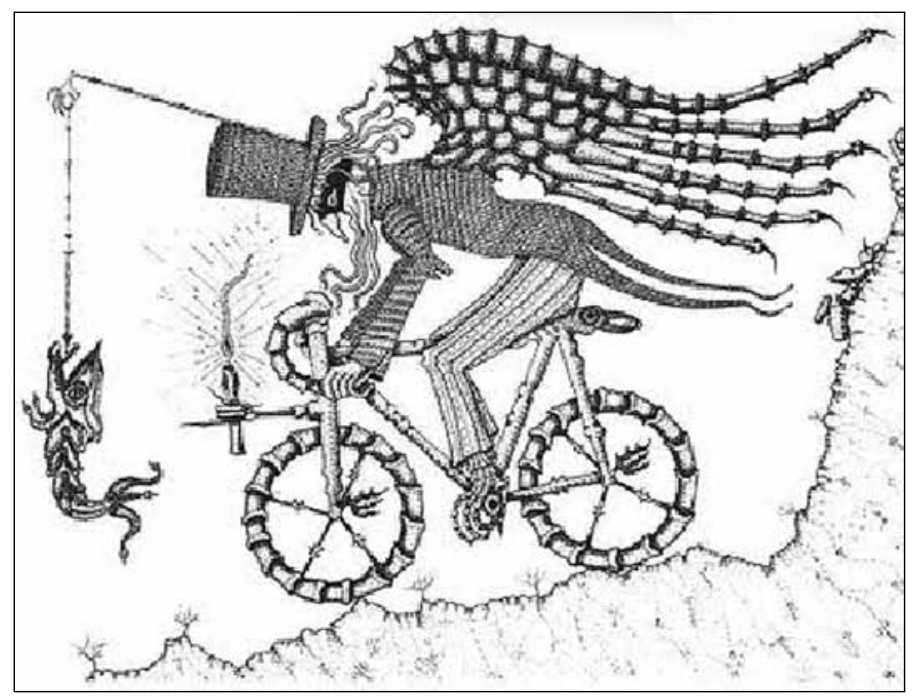

Fig.3 Dibuix original de Ponç per 97 notes sobre ficcions poncianes.

A 97 notes sobre ficcions poncianes Foix descriu un dels quadres d'en Ponç de la manera següent: "Potser hi ha de tot en aquest reialme de la por sense basarda, de l'home abans o després de l'home, de la confusió —o de la fusió- en imprudent barreja dels tres regnes naturals. Un roc és un home, una palmera té aletes de peix i es desplaça a profunditats submarines, i un mollusc vola pels cims d'una muntanya envellutada” (Foix, Obres 324). I, tal com comenta el poeta, “...hi deu haver un llenguatge, mímic o oral, per a interpretar aquest 'no' fosc i adaptar-lo a les mecàniques d'ara. N'ignorem l'abecedari”. La recerca d'un nou “alfabet” per expressar aquesta "altra realitat" és una constant en el surrealisme. Breton ens parla d'aquesta recerca a Poèmes: "Yeux zinzolins de l'alphabet secret de toute nécessité" (Breton 140) i Foix, com molt bé analitza Mercè Tricàs, en fa al·lusió en diversos escrits al llarg de la seva vida. ${ }^{16}$

J.V. Foix utilitza la constant surrealista de presentar éssers vulgars de la realitat quotidiana al costat dels personatges més fantàstics, de la qual cosa resulten estranyes amalgames. Se serveix també, com els surrealistes, de diversos procediments literaris ${ }^{17}$ per tal de transformar els éssers reals en éssers extraordinaris: "Algun dels figurants de les teles d'En Ponç, creuríeu que acaba d'aparèixer, sibil·lí, decidit a escalar, cofat amb un capell bombí amb gires interiors de seda blanca amb inscripcions metodistes, els cràters que aparenten funerals" (Foix, Obres 312). De fet moltes de les figures de Ponç apareixen, si no amb bombí, cofats amb irreprotxables copaltes i abillats amb negres levites esfilagarsades (Fig.3).

Efectivament, la tècnica surrealista de colllocar una indumentària original al personatge per penetrar en el món fantàstic és coneguda i aplaudida per Foix: "He 
enjoyed the joke invented by Duchamp in his LHOOQ and repeated by Lorca in $E l$ público and Un viaje a la luna" (Morris 53).

97 notes sobre ficcions poncianes és un llegat molt interessant per conèixer el què pensa el poeta sobre l'art d'avantguarda i l'art tradicional acceptat per al crítica de la seva època. Foix, a traves de comentaris en defensa i enaltiment de la pintura ponciana i del pintor, exposa les seves idees sobre el vertader art d'avantguarda — de descobriment, de recerca, d'invenció, sense oblidar la tradició- el qual, es convertirà en el full de ruta, tant del poeta com del pintor, al llarg de les seves obres:

No hi ha un art d'avantguarda, ni una literatura: hi ha múltiples avantguardes en les exploracions plàstiques $\mathrm{i}$ retòriques que, un cop premudes, passen a l'acadèmia, al museu o a l'asil dels desnonats. Picasso, Miró, Dalí, contemporanis i quasi coetanis, no s'assemblen gens en llurs obres i fins s'oposen. Els sentíssiu raonar: tots tres es tenen per avantguardistes. Va haver-hi una avantguarda futurista i bel-licosa d'inspiració italiana, que a França es capgirà en cubista i a Suïssa es desintegrà en dadaista. Va haver-hi, a França, una avantguarda "surrealista" —esotèrica, alquímica- que de poc no esdevé ocultista. A Alemanya l'avantguarda era expressionista i feculenta... (Foix, Obres 327).

J.V. Foix se sent completament identificat amb la pintura de Ponç. Ambdós innovadors, defugen de les modes i les convencions. Foix, a 97 notes sobre ficcions poncianes comenta que "una bona pintura i un bon llibre deslliuren i alliberen autors i receptors", i en un moment donat explica que "els qui endogalen la poesia voldrien endogalar, també, la pintura; però el pintor, mestre o aprenent, salva, com el poeta, els segles amb vol lleuger. La moda i el mode no compten gaire. Ni menys la crítica establerta". I una mica més endavant, Foix comenta que poetes i pintors van a la mateixa barca i els "vents bufen quan i on volen, però la nostra voluntat, la nostra intenció o el nostre projecte poden salvar-nos del fracàs. Aquell qui té què dir no té cura ni dels censors a sou fix ni dels mercaders de noms". I tanca el paràgraf amb una sentència que exalça les virtuts de Ponç i, en certa manera, les d'ell mateix: "Si sou prou original, si interiorment sou un reeixit, un integrat, la ruta dels estels és a peu pla" (Foix, Obres 316).

La idea moral de 'ser un mateix' és recurrent en el text, i el poeta insisteix diverses vegades. Per exemple, quan diu que "el mèrit... d'un artista, plàstic o retòric, és no enganyar-se ell mateix" (Foix, Obres 331) o quan comenta, fent referència a l'avantguarda, que "cadascú és la seva pròpia avantguarda, quan cadascú és ell", i adverteix de no caure en el parany: "El perill per a un artista és de creure que tot el que fa val. No és bo de creure's perfecte: és una malaltia de l'esperit que cal curar i guarir sense tardança. També l'escriptor, el pot vèncer l'urc" (Foix, Obres 333).

M'agradaria tancar aquest apartat amb una sentència foixiana molt bonica en defensa de l'artista plàstic o retòric: "Els bells camins es multipliquen allà on creieu 
que acaba la carretera. Un artista, músic, pintor, poeta o arquitecte neixen de nou, cada dia, amb l'aurora” (Foix, Obres 329).

\section{J.V. FOIX I ANTONI TÀPIES, UN ESTRANY MAGNETISME QUE SOVINT UNIA EL NOSTRE ESPERIT, UNA IRRADIACIÓ MÚTUA QUE ENS ENLLAÇAVA}

J.V. Foix i el jove Antoni Tàpies (Barcelona, 1923-2012) varen establir una relació molt especial que es nodria mútuament i es reforçava amb el temps. Segons Arnau Puig, el poeta va sentir un interès i una curiositat infinita per l'obra del pintor "que avançava inexorablement pels misteris i la descriptització de les matèries, convertint aquestes en quelcom de viu i expressiu, com les mateixes consciencies, i no deixar-les pas en simples suports" (148). Foix admira el Tàpies innovador i n'elogia el "deliri de ruptura i afany insatisfet de renovació" (Foix, Obres 324).

El poeta ha estat present en l'abundant bibliografia d'Antoni Tàpies, des del primer text que l'evoca, titulat Memòria personal, fins al discurs El poeta J.V. Foix i la pintura llegit en l'acta de concessió al poeta de la Medalla d'Or de la Generalitat de Catalunya, celebrat a Barcelona el 1981. Tal com el pintor explica, entre ells "esdevingué un estrany magnetisme que sovint unia el nostre esperit, una irradiació mútua que ens enllaçava: la trobada, potser, en aquell món misteriós de l'inconscient, quan l'individual es torna col·lectiu” (Tàpies, Serra d'Or 20). Efectivament la compenetració ideològica entre ambdós autors, el "magnetisme" que fa al·lusió Tàpies, es fa palesa en sengles reflexions: Segons Foix, els poetes i els artistes "per mitjà de símbols nous, retroben allò que és etern" (Carbonell 155), i la seva tasca "és la d'alliberar-se ells mateixos en llur obra, i és d'aquesta alliberament que la comunitat a la qual pertanyen i que no refusen es beneficiarà" (Tàpies, Vitalitat 25). També, per en Tàpies, poetes i pintors són "intermediaris o aproximadors d'un patrimoni comú, potser allò que uns pensem que és l'Absolut distant i que nosaltres volem pròxim, aquí i ara mateix" (Tàpies, Per un art 94). I, com Foix, el pintor insisteix que "la missió dels artistes i dels poetes és promoure la reflexió, desvetllar, atreure l'atenció, fer conèixer, il·luminar la realitat i, en suma, exaltar tot el que ens faci més lliures i més perfectes com a humans" (Tàpies, L'art d'avantguarda 32).

La collaboració més destacable entre els dos autors la trobem a l'obra L'estació $^{18}$, de l'any 1984. Als 92 anys, J.V. Foix publica el seu text acompanyat de cinc gravats a l'aiguafort d'Antoni Tàpies, els quals, en declaracions de Foix a El País (29 de gener 1985), estan “inspirats d'una manera molt subjectiva” per part del pintor. El poema en prosa, que el mateix Foix qualifica d'automàtic, descriu un dels seus somnis recents sobre "el més enllà, en el que hi ha després de la mort". 

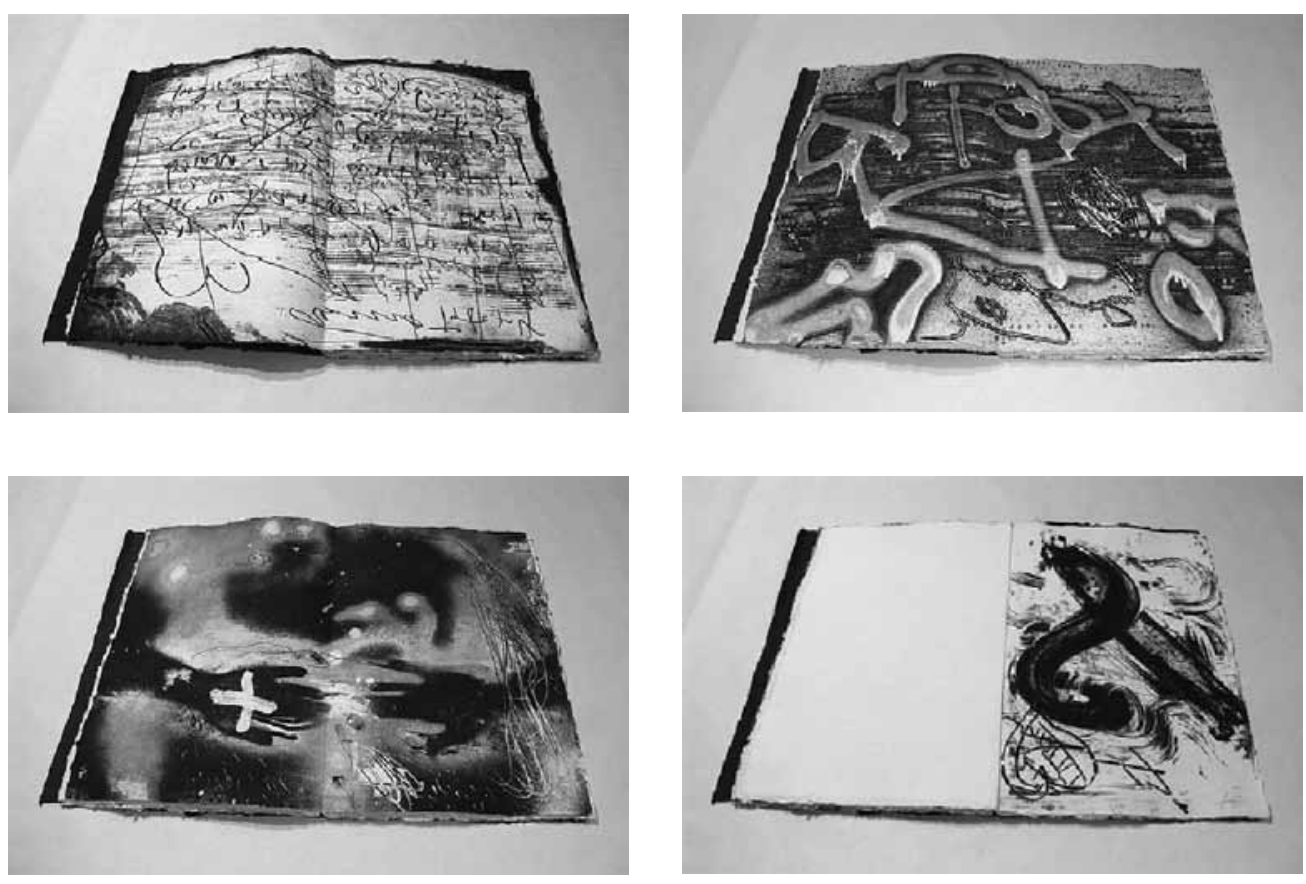

Fig. 4 Antoni Tàpies, quatre gravats de L'estació.

En realitat, l'únic tema que li preocupa des que va superar els 90 anys. Adoptant la tècnica surrealista de partir d'una realitat, el poeta s'endinsa en un somni: Estava sol en un camí solitari i de cop "un home sense pal ni consigna [...] va comparèixer davant meu i va lliurar-me una papereta, en la qual, en lletres lluminoses, hi havia inscrita una llegenda curta: 'L'estació és allà' [...] Vaig seguir la consigna [...] i vaig trobar-me, de sobte, en un amplíssim camp de pedruscall, amb rocs i còdols de grandària diferent [...] De cop va aparèixer un altre desconegut, el qual va lliurar-me, com el primer, una papereta que, en lletres també lluminoses, deia: 'L'estació és allà'. Assenyalava nord-est”. Altra volta pel mateix camí “centenars de diamants, milers de pedres precioses...” fins arribar davant d'un palau, com els que es reprodueixen en els llibres d'història, amb unes columnes magnífiques "on hi havia gravats passatges històrics i anècdotes bíbliques [...] Vaig mirar enlaire, molt enlaire, i damunt l'extraordinari edifici hi havia unes lletres grandioses i lluminoses on llegia hom: L'ESTACIÓ”. Per a Foix, en el seu somni aquest moment li va semblar únic: "un personatge, vestit amb uniforme reial ... va allargar el braç i va donar-me un tiquet que, prèviament, havia perforat [...] El tren ja era fora: havia fet tard". Es va girar i el palau havia desaparegut. Només veu un "pobre home amb despulles de deixalles d'ermità, barballarg i peunú" carregat de llibres i papers antics que li entrega un altre paper: "Sempre fareu tard". Va arribar la boira, "una 
negror que ho cobria tot" i "vaig endevinar la meva desaparició total, entre un cel de fums i boirassa".

Segons Tàpies, els aiguaforts (Fig. 4) que acompanyen el text actuen "com una mena de música de fons, un acompanyament plàstic" (Borja-Villel). El pintor busca plasmar aquesta atmosfera surrealista del somni, amb un cel de fum i de boira, on el negre - únic color esmentat en el text de Foix-, ho cobreix tot. Aquests gravats, d'una gran força i potencia expressiva, s'equiparen perfectament als sentiments i emocions més íntimes del poeta quan, a les seves velleses, fa balanç de la vida.

Si bé és cert, tal com apunta Ainaud Escudero (156), el text i les il-lustracions varen ser creats de forma separada, es pot copsar, en paraules de Gimferrer, la "conjuminació irrepetible" entre les dues manifestacions artístiques: Utilitzant, de fet, només el blanc i el negre Tàpies obté — d'un art plàstic essencialment al·lusiu, tot i la fascinadora materialitat- l'evocació del clima oníric, postsurrealista, de la seva pintura dels anys en què va conèixer a Foix i opera una síntesi, una recapitulació de la pròpia evolució, perfectament paral-lela al balanç de la vida humana que trobem als mots foixians.

Sense cap mena de dubte, l'obra L'estació és el llegat d'un testimoni visual i poètic d'una mateixa manera de sentir i expressar-se de dos grans artistes cabdals de la cultura catalana.

\section{CONCLUSIÓ}

El llegat de J.V. Foix en llibres d'artista és molt important, no tan sols per la projecció internacional dels artistes plàstics que van colllaborar amb l'escriptor, sinó perquè se'ns presenta una oportunitat d'apropar-nos a un literat insigne des d'una vessant artística, on la conjuminació entre la literatura i les arts plàstiques fan de la lectura un plaer.

Ja hem comentat com la comunió entre la paraula i la imatge en les obres de Foix-Miró, coetanis, Foix-Ponç o Foix-Tàpies, és extraordinària: La suma dels talents i la confluència dels genis fan possible parlar no de llibres il-lustrats sinó d'una obra d'Art entesa com un artefacte amb mecanismes i ressorts conceptuals, més que com un simple suport d'un text. Parafrasejant a Vicenç Altaió, els llibres d'artista que referenciem creen una cultura que no fa distinció entre judicis i sentits verbals i no verbals, entre expressió i comunicació, assenyalant la 'no-distinció' entre llegir i mirar, escriure i pintar, en definitiva, entre la cultura anomenada escrita i la cultura visual. Com hem intentat demostrar aquesta no distinció entre poesia i art és una constant que comparteixen l'escriptor i els pintors analitzats. La idea que un pintor és un poeta i que el poeta és un pintor és un joc de paraules que es repeteix en les reflexions dels autors comentats. 
La fascinació per l'art d'avantguarda, especialment el moviment surrealista, va unir els interessos dels artistes i de l'escriptor, va enfortir lligams d'amistat i de colllaboració que, en alguns casos, va durar tota la vida del poeta, com va ser la relació de Foix amb Miró. Hem vist com, en llurs produccions creatives, partint d'un escenari real que resulta familiar a l'espectador, els signes — visuals i lingüístics-, utilitzats segons les tècniques surrealistes, elaboren contínues mutacions i transformacions. L'amalgama d'elements assimilats, fent servir lleis allunyades del raonament lògic, fa possible el trasllat a un escenari que, a vegades, a força de ser irreal dóna lloc a una obra allunyada de qualsevol lligam del món conegut. J.V. Foix, com Dalí, Miró o Ponç, amb un virtuosisme incomparable, fa el salt al món oníric fent-se seus els objectius que André Breton proclamava en els manifestos surrealistes: "Qui no és somnàmbul, no és poeta" escrigué Foix a La publicitat (29-VII-1934) però advertí que "[...] qui no és crèdul, no és tampoc poeta. Somnambulisme i credulitat, doncs" malgrat que "no tothom pot abastar la mà misteriosa —i divina-que guia el somnàmbul" (Carbonell 71).

Segurament, l'interès de J.V. Foix pels llibres d'artista li ve donada, en part, per la seva relació amb el món editorial. Des de ben jove, el 1917, Joaquim Folguera el va incorporar a La Revista i l'any següent va ser director de Trossos, que havia fundat Josep Maria Junoy. L’any 1922, Foix va encetar la seva col-laboració en $\mathrm{La}$ publicitat, diari mític de la secció de cultura del qual esdevingué cap fins a l'esclat de la guerra civil, l'any 1936. Paral-lelament al Foix periodista, es covava el Foix literari i ja a l'any 1927 va publicar el primer llibre de prosa poètica anomenat Gertrudis i, poc després, l'any 1932, KRTU. Ambdós eren part integrant d'un extens diari que Foix datava el 1918. Obres primerenques de marcada influència surrealista que són el reflex de les inquietuds de Foix per tot allò innovador que es covava a Europa i que marcaran un estil propi que deixarà una empremta a la seva creació literària posterior.

Si a la vocació periodística i literària de Foix li sumem el talent, el caràcter inquiet i creatiu, i l'afany investigador de tot el que "és nou", sense oblidar la tradició, ens trobem davant d'un personatge universal, amb un llegat molt important dins de la nostra cultura catalana. I dins d'aquest llegat, els llibres d'artista hi juguen un paper destacat per la confluència entre la literatura i l'art plàstic que tan defensava el poeta. L'any 1985, en una taula rodona a l'Ateneu de Barcelona, Foix va dir: "un poeta era un artista plàstic i un bon artista plàstic ja era un poeta", idea que també preconitzà Tàpies o Miró en més d'una ocasió. ${ }^{19}$

Els llibres d'artista que presentem són la comunió perfecte entre el poeta i l'artista plàstic. En una dissertació a La publicitat, l'escriptor atribueix qualificatius i característiques del llibre d'artista a la poesia: "Els poemes no s'haurien d'editar aplegats en un llibre ans bé un a un, per fulls periòdics i amb un estudi dels blancs tipogràfics tan complet que ells sols ja constituïssin una obra mestra. La qualitat 
del paper, el seu color, serien tan essencials com la rima (o l'assonància ), i l'olor de la tinta hi jugaria un paper eminent" (Carbonell, 52). També Tàpies es sentí atret per l'artisticitat dels llibres, - fet gens particular si tenim en compte que prové d'una nissaga d'editors i llibreters: “M'agradava sentir-los entre les mans. A mi m'ha arribat a impressionar molt l'olor d'un llibre. Els llibres, els seus aspectes materials, parlen molt de l'estètica i de la història d'una època" (Borja-Villel). I, en certa manera, aquest article ha volgut tractar una faceta del J.V. Foix no gaire estudiada i, en canvi, molt interessant perquè els llibres d'artista ens ofereixen una altra lectura de la seva obra: Una lectura pausada, contemplativa, visual i tàctil, plena de cromatismes, referències oníriques, metàfores plàstiques que al·ludeixen a la paraula escrita pel poeta... I és en aquests llibres d'artista, juntament amb els poemes de pedra on, al meu entendre, es fa més pal·les l'amor de Foix per la literatura-art.

\author{
EVA FIGUERAS FERRER \\ Universitat de Barcelona
}

\title{
NOTES
}

1 La revista es va publicar tres anys sense interrupció, del 1926 al 1929. Després d'una època de silenci apareix el darrer número l'any 1930. Aquesta data que marca la fi de l'etapa avantguardista més important, ja que amb la proclamació de la República, les publicacions d'aquesta mena desapareixen de la cultura catalana, talment perquè temes com "ordre" $\mathrm{O}$ "innovació" adquireixen, amb el canvi de règim polític, accepcions diferents. Tanmateix l'esperit d'avantguarda quedarà latent en la literatura i l'art, i moltes produccions posteriors són d'una manera o una altra deutores de l'esperit de renovació iniciat en aquesta època. Per informació sobre L'Amic de les Arts veure: Garcia de Carpi (66-68) i Morris (15-16).

2 Personatge eclèctic, J.V. Foix va ser un gran coneixedor de les plomes clàssiques de casa nostra com són Ramon Llull i Ausiàs March. L'escriptor es confessava, també, un gran admirador de Jacint Verdaguer i dels coetanis Josep Carner i Carles Riba, així com també dels escriptors toscans Dante i Petrarca.

3 Serra d'or (1973), Quaderns de poesia (núm. 6) o a l'entrevista concedida a la revista Triunfo (21 abril 1973).

4 Vinyet Panyella en l'article "Aproximació al pensament polític de J.V. Foix" ofereix un assaig interdisciplinari, amb fonts de documentació política, literària, històrica i cultural, amb la intenció de resseguir la bibliografia intel-lectual del poeta, molt interessant i ben documentat. Veure: Catalan Review 1 (1986): 141-169.

5 El grup ADLAN (Amics de l'Art Nou) va ser una agrupació creada a Barcelona el novembre de l'any 1932. Els animadors van ser Joan Prats i Vallès, Joaquim Gomis i Josep Lluís Sert. Amics de Joan Miró i Salvador Dalí, van donar a ADLAN la possibilitat de relacionar-se amb el bo i millor de l'avantguarda artística mundial. En formaven part: J.V. Foix, S. Gasch, Ll. Montanyà i M.A. Cassanyes, així com C. Sindreu, l'escultor Àngel Ferrant, els músics Carles Maristany i Robert Gerhard. 
6. La Publicitat, un dels òrgans periodístics més destacats de la història de Catalunya, va ser el diari de l'agrupació política Acció Catalana. Des del 1922, Foix s’hi va vincular plenament i va tenir un paper important en la publicació fins a l'esclat de la guerra, el juliol del 1936.

7 Veure l'estudi de Riese (1988) 130-138.

8 Veure l'estudi de Riese (1988) 288-308.

9 Quatre colors aparien al món... Artista Joan Miró. Textos de J.V. Foix. Les Estampes de la Cometa, 16. Barcelona: Gustavo Gili, 1975. Cinc aiguaforts i aiguatintes. Format $98 \times 72 \mathrm{~cm}$. Tirada 50 exemplars.

10 Amb els ulls clucs no hi ha res impossible, totes les limitacions desapareixen. Veiem alguns exemples: "Allà on vull -dic sempre- só [...] A mi, em cal només tancar els ulls [...] si tanco els ulls, l'espai, per mi és un punt: el Punt" (Foix, Obres 216), o aquest altra, "Cada vespre, quan tanco els ulls, per adormir-me [...] les verges passen en caravana enmig d'un silenci rosa" (Foix, Obres 58).

11 La pell de la pell. Artista Joan Ponç. Text de J.V. Foix. Barcelona: La Polígrafa, 1970. Format 51.9 x $67.2 \mathrm{~cm}$. Sota el títol llegim que és una "Carta oberta a Joan Ponç, pintor”, escrita a Port de la Selva el 20 d'agost de 1968.

1297 notes sobre ficcions poncianes. Artista Joan Ponç. Textos de J.V. Foix. Barcelona: Edicions Polígrafa, 1974. Format $34.5 \times 25.5 \mathrm{~cm}$. Tiratge 516 exemplars. Tiratge especial del llibre format $56 \times 75 \mathrm{~cm}$.

13 Foix adopta la tècnica surrealista de la metamorfosi -entesa com el resultat de col-locar en un mateix pla allò objectiu i allò subjectiu, el somni i la realitat-i la converteix en una de les claus de la seva escriptura. Veure Morris 52-55.

14 Veure: La pell de la pell. Joan Ponç-J. V. Foix, exposició creada pel Museu de la Vida Rural i l'Associació Joan Ponç. (Audiovisual Fundació Lluís Carulla. Museu de la Vida Rural, 2007). [Consultat el 25/05/2013: http://museuvidarural.blogspot.com. es/2008/05/la-pell-de-la-pell-la-torre-ella-de.html].

15 Morris quan parla dels objectius, motius i tècniques que Foix comparteix amb els surrealistes fa referència a la fragmentació del cos humà: "The decapitated heads, amputated hands and bleeding eyes imagined by Foix established between his eyes and surrealist writings, paintings and Films a grisly connection reinforced by his references to his 'full interior monologue', 'my dreams' and the 'torrents of dream'” (Morris 53).

16 Mercè Tricàs en el seu estudi J.V. Foix i el surrealisme, analitza diferents fragments en prosa i en poesia on Foix fa referència a "alfabet" i/o "altra realitat", objectiu final de la recerca surrealista (93-96).

17 Alguns dels recursos literaris que es serveixen els surrealistes per transformar personatges reals en éssers màgics els exposa Mercè Tricàs (145-166).

18 L’Estació. Artista Antoni Tàpies. Textos de J.V. Foix. Barcelona: Taché editors, 1984. Inclou cinc aiguaforts de l'artista.

19 Antoni Tàpies, en el discurs en l'acte de concessió de la Medalla d’Or de la Generalitat a Josep Vicenç Foix: “...els nostres oficis fins i tot semblen intercanviables. En tinc la prova, com ho he explicat en una altra ocasió, en l'endreça que em va posar a un dels meus llibres, una de les que m'ha de fer més feliç, en tota la meva vida de pintor. Diu sencillament així: A N'ANTONI TÀPIES, POETA i signa J.V. FOIX, PINTOR A LA SEVA MANERA". 


\section{REFERENCIES}

Ainaud Escudero, Joan-Francesc. “J.V. Foix, pintor, i n’Antoni Tàpies, poeta”. J.V. Foix. Investigador en poesia $i$ amic de les arts. Barcelona: Fundació la Caixa, 1994. 155.

Altaió, Vicenç, i Manuel Guerrero. "El segle de J.V. Foix". J.V. Foix. Investigador en poesia $i$ amic de les arts. Barcelona: Fundació la Caixa, 1994. 8.

Batista, Antoni. "Entrevista. Antoni Tàpies”. Avui del Diumenge, 16 de juny 1985. 4.

Breton, André. Le surréalism et la peinture. Paris: Gallimard, 1965.

—. Breton, André. Poèmes. Paris: Gallimard, 1948.

Borja-Villel, Manuel J. "L'expressivitat del paper. Una conversa amb Antoni Tàpies". Antoni Tàpies. Obra gráfica 1947-1990. Saragossa: Gobierno de Aragón y Diputación de Zaragoza, 1994: 7-14.

Carbonell, Manuel, ed. Obres completes 4. Sobre literatura i art. Col. Clàssics catalans del segle XX. Barcelona: Edicions 62, 1990.

—. "Ressenyes". Els Marges: revista de llengua i literatura 17 (1979): 116.

Casals, Montserrat. "J.V. Foix y Antoni Tàpies, unidos en la descripción de un sueño", El País. N.p. 29 de gener 1985. Edición España. http://elpais.com/diario/1985/01/29/ cultura/475801203_850215.html. 28 de octubre 2013.

Corominas, María José, i Xavier Canals. “L.V. Foix i els artistes plàstics”. Catalan Review 1.1 (1986): 51-59.

Corredor-Matheos, J. "L’Amic de les Arts: tradició i avantguarda”. J.V. Foix. Investigador en poesia $i$ amic de les arts. Barcelona: Fundació la Caixa, 1994. 84.

Foix, J.V. “Dada”. D’ací d'allà 22.179 (1934): 48.

- Obres completes 2. Prosa. Col. Clàssics catalans del segle XX. 2na. ed. Barcelona: Edicions 62, 1985.

—. "La pintura de Joan Miró". Cahiers d’Art 9.1-4 (1934).

—, i Joan Miró. Quatre colors aparien el món... Barcelona: Gustavo Gili, 1975.

—, i Joan Ponç. La pell de la pell. Barcelona: Polígrafa, 1970.

— i Joan Ponç. 97 notes sobre ficcions poncianes. Barcelona: Polígrafa, 1974 .

—, i Antoni Tàpies. L’Estació. Barcelona: Taché editors, 1984.

García de Capri, Lucia. La pintura surrealista española (1924-1936). Madrid: Ediciones Istmo, 1986.

Gómez Inglada, Pere. "Salvador Dalí vist per J.V. Foix des de les pàgines de La Publicitat". Arts. Revista de Girona 244 (2007): 43-47.

Malet, Rosa Maria. Joan Miró. Barcelona: Edicions Polígrafa, 2003.

Morris, C.B. Surrealism and Spain. Cambridge: Cambridge University Press, 1972.

Panyella, Vinyet. "Aproximació al pensament polític de J.V. Foix". Catalan Review 1.1 (1986): 141-169.

Picazo, Glòria. "Amat: postal a J.V. Foix". J.V. Foix. Investigador en poesia $i$ amic de les arts. Barcelona: Fundació la Caixa, 1994. 162.

Prudon, Montserrat. "La peau de la peau ou le poète dit le peinture (J.V. Foix/J. Ponç)". Peinture et écriture I. Paris: Unesco, La Différence, 1996. 129-143.

Puig, Arnau. "J.V. Foix, o... sóc un testimoni del que conto, i que el real, del qual parteixo i del qual visc..., i l'irreal que tu penses descobrir-hi, són el mateix". J.V. Foix. Investigador en poesia $i$ amic de les arts. Barcelona: Fundació la Caixa, 1994. 148.

Riese Hubert, Renée. Surrealism and the Book. University of California Press, 1992 (1988). 
Roser Puig, Montserrat. "Experiments in dialogic poetics: J.V. Foix and Joan Ponç's La pell de la pell (1970)". Catalan Review 26 (2012): 36-56.

Sobrer, Josep Miquel. "Deformation, Mutilation and Putrefaction: The Early Foix". Journal of Iberian and Latin American Studies 9:2 (2003): 179-189.

Tàpies, Antoni. "L'art d'avantguarda i l'esperit català". L'art contra l'estètica, Barcelona: Ariel, 1974: 32.

-. Memòria personal. Barcelona: Crítica, 1977.

—. "Vitalitat de J.V. Foix". Reduccions 7 (1979): 25.

-. Per un art modern i progressista, Barcelona: Empúries, 1985. 94.

—. "La 'mania' de Foix". Serra d'Or XXXV, 398 (1993): 19-20.

- . "Foix i la Pintura". Discurs en concessió de la Medalla d'Or de la Generalitat a Josep Vicenç Foix, 1981.

Tricàs, Mercè. J.V. Foix i el surrealisme. Edicions Anglo-Catalanes, 1986.

Vallès i Rovira, Isidre. "L'univers simbòlic de Joan Miró, 1930-1980". D’Art. Revista del Departament d'Història de l'Art. 16 (1990): 147-165.

Vicens, Francesc. "Miró, creador d'un nou llenguatge”. Batik 41. Abril (1978): 17. 